\title{
Aplikasi Presensi Karyawan PT. Angkasa Pura I (Persero) Banjarmasin
}

\author{
Siti Nur Aisyah ${ }^{1)}$, Khairul Anwar Hafizd ${ }^{2)}$ \\ 1)2) Jurusan Teknik Informatika, Politeknik Negeri Tanah Laut \\ Jl. A.Yani Km.6 Pelaihari Tanah Laut Kalimantan Selatan \\ Telp. (0512) 21537, Faks. (0512) 21537 \\ 1)aisyahsyahai@gmail.com \\ ${ }^{2)}$ Khairul.awarhafizd@gmail.com
}

\begin{abstract}
Abstrak - Pesatnya perkembangan teknologi membuat perusahaan - perusahaan memperbaharui fungsi sistem yang berjalan. Sebagai contoh PT. Angkasa Pura I (Persero) Banjarmasin yang dalam proses absensi untuk karyawan menggunakan alat finger print dimana alat tersebut tidak bersifat fleksibel karena posisi alat menempel pada dinding serta proses rekapitulasi data absensi karyawan dilakukan dengan mengambil data dari database dengan menggunakan flaskdisk lalu selanjutnya di cetak/print out menjadi laporan absensi. pengelolaan data absensi dapat dilakukan secara terkomputerisasi menggunakan database yang langsung dihubungkan dengan monitor yang menampilkan seluruh data yang ada, sehingga dapat mempercepat dan mempermudah dalam pengecekan dan pengolahan data. Database tidak hanya digunakan sebagai tempat penyimpanan, tetapi juga memberikan kecepatan dan kemudahan dalam mencari data, dapat menampilkan data yang akurat, menawarkan sistem security untuk keamanan data, laporan yang dicetak dapat berupa file excel ataupun file pdf. Tentu hal ini menjadi solusi untuk membantu karyawan dalam melakukan absensi tanpa harus menuju ke ruang lobby kantor, membantu admin dalam proses rekapitulasi data absensi dan memberikan fasilitas kepada general manager untuk melakukan monitoring terhadap absensi karyawan.
\end{abstract}

Kata Kunci : Absensi, Karyawan, Database

\section{PENDAHULUAN}

Perkembangan suatu perusahaan ditentukan oleh bagaimana cara perusahaan dalam memanfaatkan teknologi yang ada, baik itu teknologi yang sederhana maupun teknologi yang kompleks. Keberhasilan dalam sebuah perusahaan tidak pernah lepas dari kedisiplinan semua stakeholder yang ada. Kedisiplinan berkaitan erat dengan presensi kehadiran karyawan. Presensi digunakan untuk mengetahui sejauh mana tingkat disiplin kerja karyawan, apakah karyawan tersebut bisa mentaati peraturan yang diterapkan atau tidak atau proses rutin pengumpulan data dan pengukuran kemajuan atas objektif program atau memantau perubahan, yang fokus pada proses dan keluaran.

Sistem presensi atau absensi karyawan pada PT. Angkasa Pura I (Persero) Banjarmasin yang digunakaan saat ini adalah dengan finger print yaitu sistem absen yang dilakukan dengan menempelkan salah satu jari pada alat sehingga alat akan merekam sidik jari dan menjadikannya primary key untuk absensi masing-masing karyawan yang berbeda dengan karyawan lainnya. Tetapi absensi ini memiliki beberapa kekurangan, yaitu:

1. Kecurangan dalam pembuatan database finger print.

2. Posisi alat finger print terlalu jauh dari ruang karyawan.

3. Alat kadang-kadang memerlukan waktu lama untuk mengenali finger print karyawan.

4. Pengolahan data finger print dilakukan secara konvensional.

Solusi dari permasalahan di atas yaitu perlu adanya suatu sistem atau device yang dapat memenuhi kebutuhan perusahaan terkait dengan permasalahan absensi perusahaan dengan melakukan perancangan dan pembuatan aplikasi absensi karyawan yang dapat mempermudah karyawan dalam melakukan absensi dan membantu admin dalam merekap data, serta dapat membantu perusahaan dalam memonitoring kualitas kerja karyawan. Pembuatan aplikasi ini menggunakan bahasa pemrograman PHP dan database MySQL.

Berdasarkan latar belakang permasalahan tersebut maka penulis mengangkat judul "Aplikasi Presensi Karyawan PT. Angkasa Pura I (Persero) Banjarmasin".

\section{LANDASAN TEORI}

Bagian ini memuat teori-teori pendukung untuk membangun aplikasi absensi karyawan menggunakan PHP yang telah dirancang menggunakan Unified Modeling Language(UML), meliputi class diagram, object diagram, use case diagram, activity diagram, dan sequence diagram.

\subsection{Aplikasi}

Aplikasi adalah program yang ditulis untuk melaksanakan tugas khusus dari pengguna. Jenis program ini mempunyai sifat pasti tentang pemprosesan yang harus dilakukan file data yang harus di proses guna menyelesaikan suatu pekerjaan (Nugroho, 2007).

Aplikasi adalah kumpulan perintah program yang dibuat untuk melakukan pekerjaan-pekerjaan tertentu (Hendrayudi, 2009).

Berdasarkan beberapa definisi dari para ahli diatas dapat disimpulkan bahwa aplikasi merupakan sebuah program siap pakai yang dibuat dalam sebuah 
perangkat lunak dengan komputer untuk memudahkan pekerjaan atau tugas-tugas seperti penerapan, penggunaan dan penambahan data yang dibutuhkan. Dalam sebuah komputer aplikasi ini disiapkan sesuai kebutuhannya masing-masing.

\subsection{Absensi}

Pengertian absensi menurut penulis adalah sebuah proses pengambilan data guna mengetahui jumlah kehadiran pada suatu acara ataupun kegiatan. Setiap kegiatan yang membutuhkan informasi mengenai peserta tentu akan melakukan absensi.

Absensi karyawan merupakan pengambilan data kehadiran yang dikhususkan untuk karyawan pada instansi atau perusahaan. Proses absensi karyawan dapat dengan cara konvensional ataupun dengan menggunakan teknologi. Dengan adanya absensi dapat menjadi tanggung jawab karyawan terhadap institusinya.

\subsection{ERD (Entity Relationship Diagram)}

ERD adalah pemodelan awal basis data yang paling banyak digunakan. ERD memiliki beberapa aliran notasi seperti notasi Chen (dikembangkan oleh Peter Chen), Barker (dikembangkan oleh Richard Barker, Ian Palmer, Harry Ellis), notasi Crow's Foot, dan beberapa notasi lain (Rosa dan Salahudin, 2013).

\subsection{UML (Unified Model Language)}

Pada perkembangan teknik pemograman berorientasi objek, munculah sebuah standarisasi bahasa pemodelan untuk pembangunan perangkat lunak yang dibangun dengan menggunakan teknik pemograman berorientasi objek yaitu Unified Modeling Language (UML). UML muncul karena adanya kebutuhan pemodelan visual untuk menspesifikasikan, menggambarkan, membangun, dan dokumentasi dari sistem perangkat lunak. UML merupakan bahasa visual untuk pemodelan dan komunikasi mengenai sebuah sistem dengan menggunakan diagram dan teks-teks pendukung. Terdapat 9 diagram UML menurut Rosa dan Salahudin (2013), yaitu:

1. Use Case Diagram

2. Class Diagram

3. Activity Diagram

4. Object Diagram

5. Sequence Diagram

6. Communication Diagram

7. State Machine Diagram

8. Deployment Diagram

9. Component Diagram

\section{ANALISIS SISTEM}

Analisis sitem yang dilakukan dalam pembuatan aplikasi absensi karyawan dibagi menjadi 2 (dua) tahap, yaitu analisis sistem yang berjalan dan analisis sistem yang diusulkan.

\subsection{Analisis Sistem yang Berjalan}

Sistem absensi karyawan pada PT. Angkasa Pura I (Persero) Banjarmasin adalah dengan menggunakan alat finger print. Sistem yang ada saat ini masih dianggap kurang efektif dikarenakan posisi alat yang jauh serta proses rekapitulasi data yang harus mengambil memori alat terlebih dahulu tidak langsung dapat dimonitor dan dicetak. Gambaran absensi karyawan PT. Angkasa Pura I (Persero) Banjarmasin:

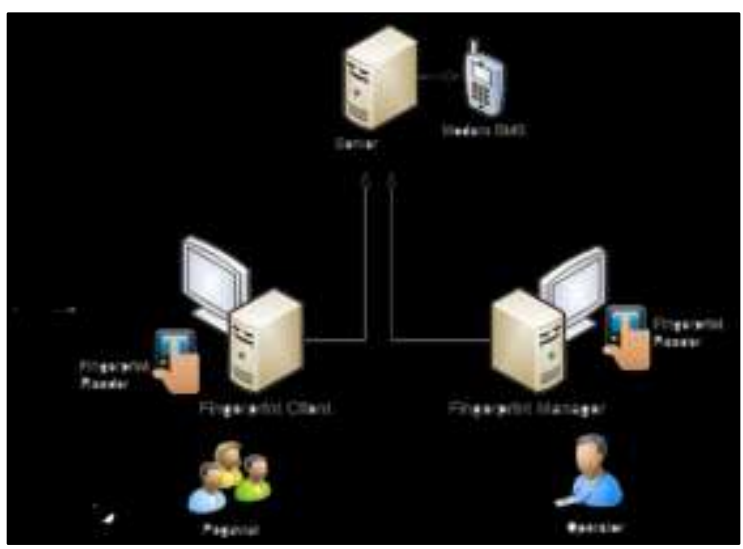

Gambar 1. Sistem yang Berjalan

\subsection{Analisis Sistem yang Diusulkan}

Mereferensi dari kelebihan dan kekurangan dari sistem yang berjalan di PT. Angkasa Pura I (Persero) Banjarmasin, gambaran sistem absensi karyawan yang diusulkan:

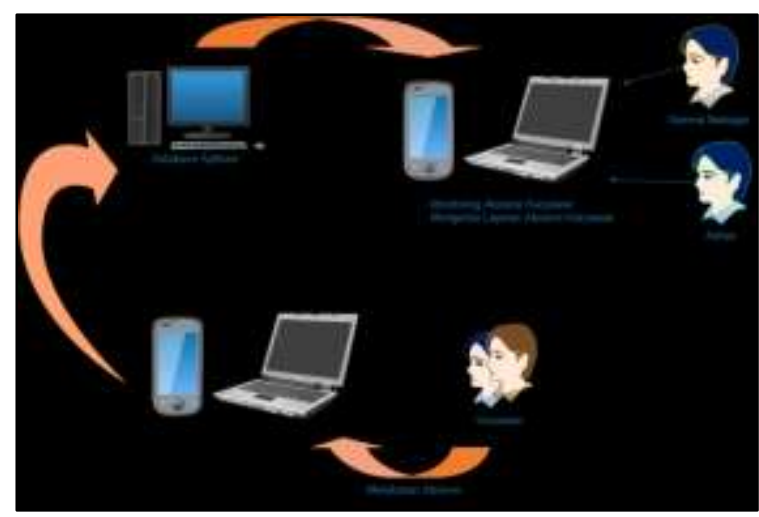

Gambar 2. Sistem yang Diusulkan

\section{PERANCANGAN DAN IMPLEMENTASI SISTEM}

\subsection{Perancangan Sistem}

Aplikasi absensi karyawan ini dirancang menggunakan ERD (Entity Relationship Diagram) untuk merancang databasenya, serta menggunakan Class Diagram, Object Diagram, Use Case Diagram, Activity Diagram, dan Sequence Diagram untuk merancang aplikasinya.

\subsubsection{Entity Relationship Diagram (ERD)}

Entity Relationship Diagram menggambarkan data dan hubungan antar data secara global dengan menggunakan Entity Relationship Diagram. 
Gambaran Entity Relationship Diagram pada Aplikasi Absensi Karyawan:

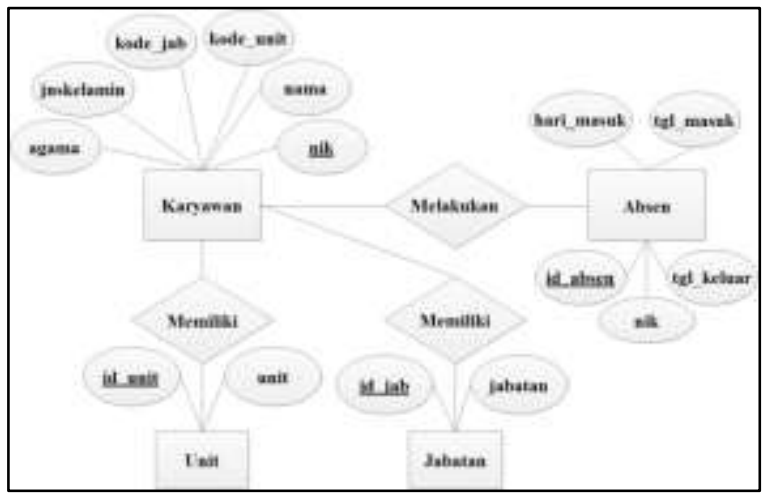

Gambar 3. Entity Relationship Diagram

Tabel 1 Tabel Definisi Relasi

\begin{tabular}{|l|l|l|}
\hline No & Nama Relasi & \multicolumn{1}{|c|}{ Keterangan } \\
\hline 1. & $\begin{array}{l}\text { Melakukan } \\
\text { absensi }\end{array}$ & $\begin{array}{l}\text { Relasi antara tabel karyawan dan tabel } \\
\text { absen yang dapat menampilkan data } \\
\text { absensi sesuai dengan karyawan yang } \\
\text { melakukan absensi }\end{array}$ \\
\hline 2. & Memiliki unit & $\begin{array}{l}\text { Relasi antara tabel karyawan dan tabel } \\
\text { unit yang dapat menampilkan data } \\
\text { unit dari karyawan tersebut }\end{array}$ \\
\hline 3. & $\begin{array}{l}\text { Memiliki } \\
\text { jabatan }\end{array}$ & $\begin{array}{l}\text { Relasi antara tabel karyawan dan tabel } \\
\text { jabatan yang dapat menampilkan data } \\
\text { jabatan dari karyawan tersebut }\end{array}$ \\
\hline
\end{tabular}

\subsubsection{Use Case Diagram}

Use Case Diagram mendeskripsikan interaksi antara pengguna dengan sistem. Use case diagram digunakan untuk mengetahui fungsi yang ada di dalam sebuah sistem informasi dan siapa saja yang berhak menggunakan fungsi itu. Use Case pada Aplikasi Presensi Karyawan dapat dilihat pada Gambar 4.

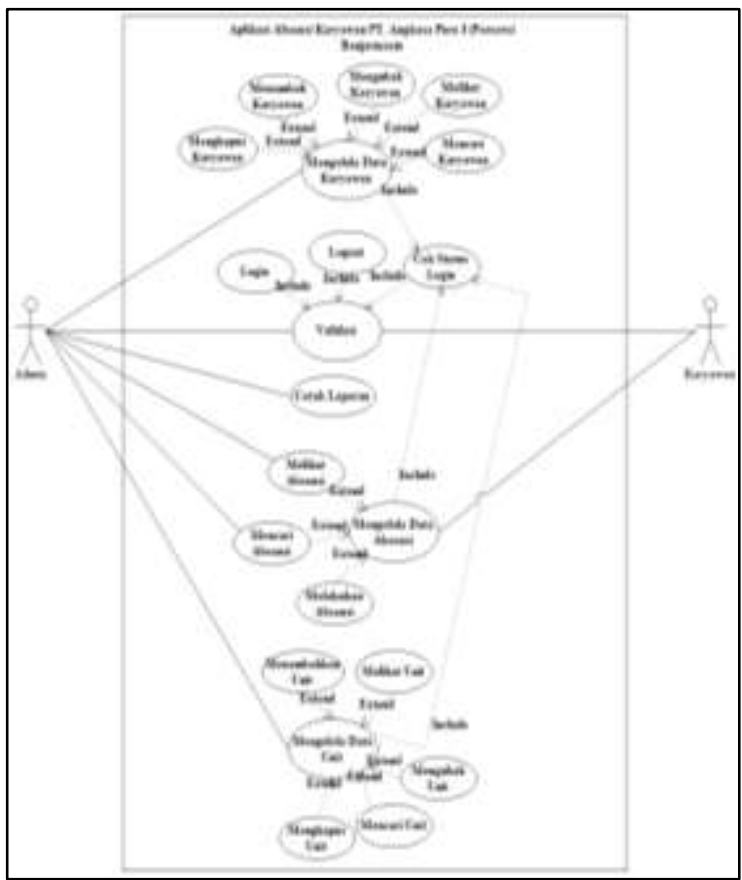

Gambar 4. Use Case Diagram

\subsubsection{Activity Diagram}

Activity Diagram menggambarkan workflow (aliran kerja) atau aktivitas dari sebuah sistem atau proses bisnis. Gambar Activity Diagram admin pada Aplikasi Absensi Karyawan:

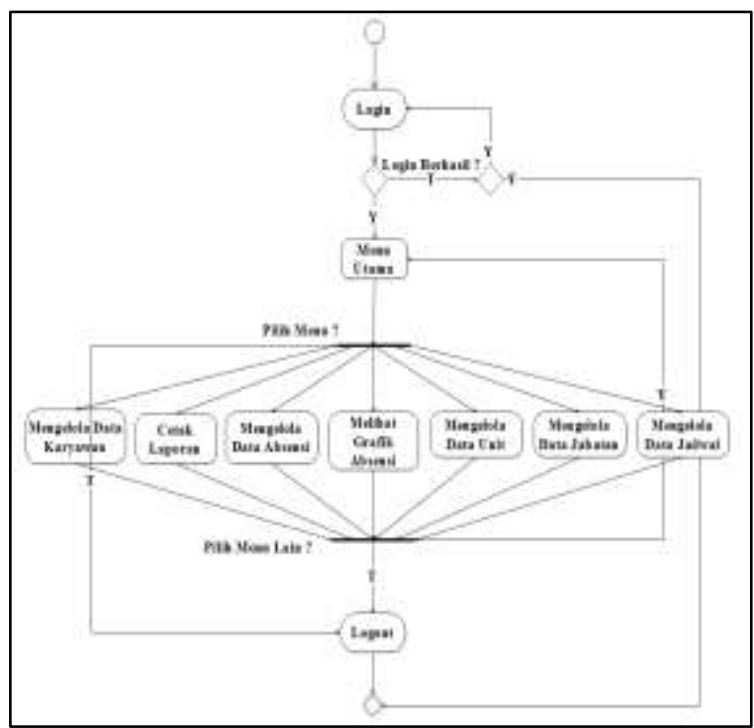

Gambar 5. Activity Diagram Admin

Pada tahap ini menggambarkan aktivitas yang terjadi pada aplikasi saat admin pertama kali mengaktifkan aplikasi, urutan prosesnya adalah di mulai dari status awal menuju login setelah itu ada percabangan jika datanya valid (y) maka akan menuju tampilan menu (Kelola Data Karyawan, Kelola Data unit, Kelola Data Jabatan, Melihat Absensi, Cetak Laporan) jika tidak (t) menuju percabangan lagi apakah mau login lagi, jika ya (y) maka akan menuju ke login jika tidak maka akan menuju ke logout dan status akhir.

Gambar Activity Diagram User pada Aplikasi Absensi Karyawan:

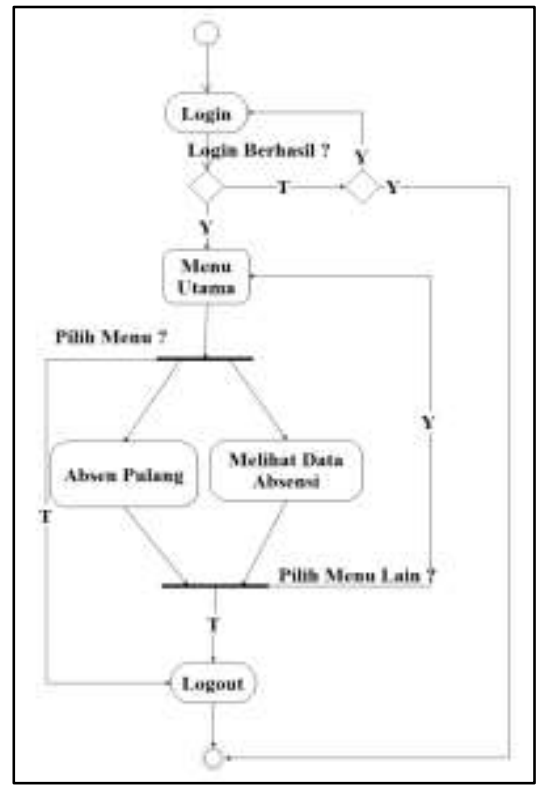

Gambar 6 Activity Diagram User 
Pada tahap ini menggambarkan aktivitas yang terjadi pada aplikasi saat karyawan pertama kali mengaktifkan aplikasi, urutan prosesnya adalah di mulai dari status awal menuju login atau absen masuk, setelah itu ada percabangan jika datanya valid (y) maka akan menuju tampilan menu (Melihat Data Absensi atau Logout) jika karyawan memilih menu Logout maka akan otomatis absen keluar dan menuju ke logout dan status akhir.

\subsection{Implementasi Sistem}

Implementasi sistem dari Aplikasi Absensi Karyawan pada PT. Angkasa Pura I (Persero) Banjarmasin .

\section{Form Login}

Form login berfungsi untuk memberikan hak akses kepada pengguna agar dapat masuk ke Aplikasi Absensi yang dibangun. Jika username dan password yang dimasukkan berstatus sebagai admin, maka akan masuk ke menu khusus untuk admin, jika username dan password yang dimasukkan berstatus sebagai user, maka akan masuk ke menu khusus untuk user dan langsung tercatat sebagai absen masuk sehingga proses login merupakan proses absen masuk karyawan. Form login dapat dilihat pada Gambar 7.

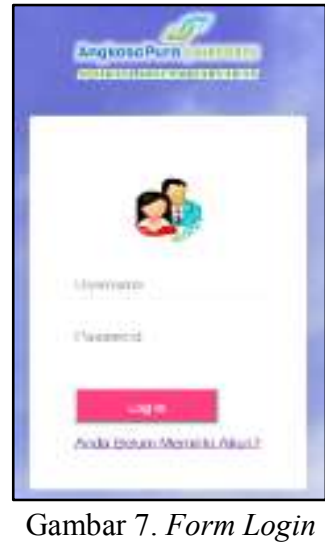

\section{Form Beranda Admin}

Form beranda admin adalah halaman utama dari Aplikasi Absensi Karyawan setelah melakukan login. Form Beranda Admin dapat dilihat pada Gambar 8.

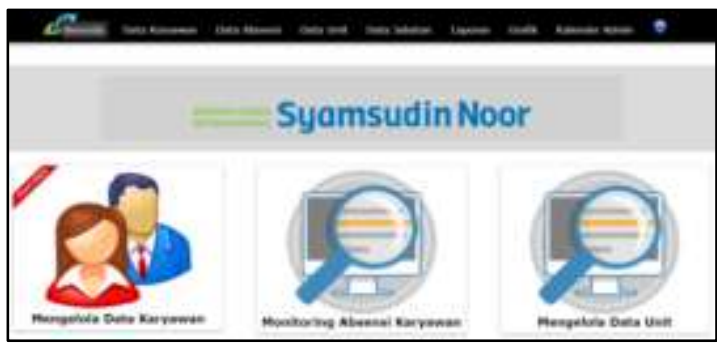

Gambar 8. Form Beranda Admin

\section{Form Data Karyawan Admin}

Form Data Kategori Admin untuk mengelola semua data karyawan. Dalam tiap menu tersebut ada fungsi tambah, edit, hapus, lihat, dan cari data. Form data karyawan admin dapat dilihat pada Gambar 9.

\begin{tabular}{|c|c|c|c|c|c|}
\hline $\mathbf{x}$ & Suneinka & 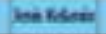 & $m$ & tenten & as. \\
\hline tweE: ? & sivale & Prenos & Fersits & posats & 200 \\
\hline $\tan x$ & Nosesh & prover & Foracé & poemeres & 106 \\
\hline Ineds & Nhat Nharrad & pan & ing & porrine & 100 \\
\hline inestal & Sintat Sharnat & bisk & दा & peomeriat & 100 \\
\hline Exant & fartisth & Armax & hanitye & bef & 200 \\
\hline mimat & hat ins & bisk & tarn; & partitur & 206 \\
\hline ment & Det timnt & bis & $t=1$ & sif & 106 \\
\hline
\end{tabular}

Gambar 9. Form Data Karyawan Admin

\section{Form Data Absen}

Form Data Absen untuk memonitoring data absen karyawan dapat dilihat pada Gambar 10.

\begin{tabular}{|c|c|c|c|c|c|}
\hline Do Hes: & Name Imokap & Sarikent & Mea Mienk & lantiber & Konmeses: \\
\hline $3993333 \mathrm{H}$ & poobkintent: & $\omega e c-n-\infty)$ & 90000 & 16:419 & 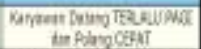 \\
\hline $1236656-4$ & petakst & xos-900 & cosecti & ot:at:27 & 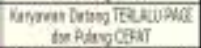 \\
\hline $1250566 \mathrm{~h}$ & monst $5 t$ & $\omega(x-2)-\infty)$ & $\omega x=0$ & 4:an & 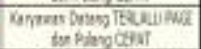 \\
\hline 61) 604 & loostsits & 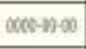 & $69 x+15$ & (t).11:3a & 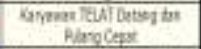 \\
\hline 1220235 & Suesitu & $\alpha a n-\infty)$ & worste & Dishag & 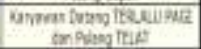 \\
\hline
\end{tabular}

Gambar 10. Form Data Absen

\section{Form Grafik Admin}

Form Data Grafik Admin untuk menampilkan presentase absensi karyawan yang dating tepat waktu. Form grafik admin dapat dilihat pada Gambar 11.

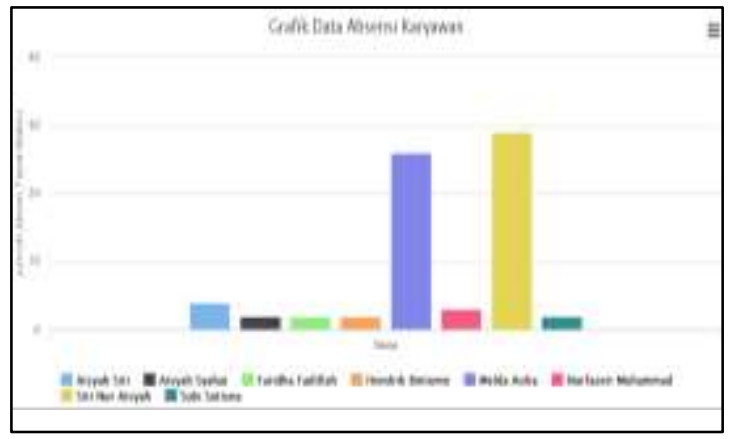

Gambar 11. Form GrafikAdmin

\section{Form Cetak Laporan Admin}

Laporan absensi karyawan yang dilakukan oleh admin dicetak berdasarkan tanggal atau periode yang diinginkan. Data dapat dicetak per-minggu, per-bulan, ataupun per-tahun sesuai dengan kebutuhan. Form cetak laporan admin dapat dilihat pada Gambar 12.

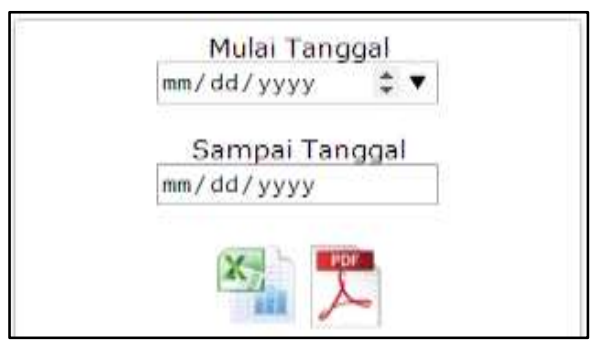

Gambar 12. Form Cetak Laporan Admin 


\section{Hasil Cetak Data Absensi}

Hasil cetak data Absensi adalah hasil dari absensi berdasarkan tanggal yang diinginkan admin. Bentuk laporan akan di export ke dalam Microsoft Excel dan file pdf. Hasil export dapat dilihat pada Gambar 13 dan Gambar 14.

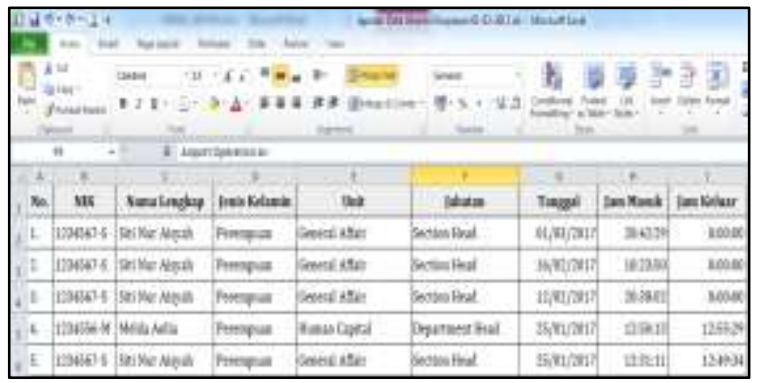

Gambar 13. Hasil Export ke Excel

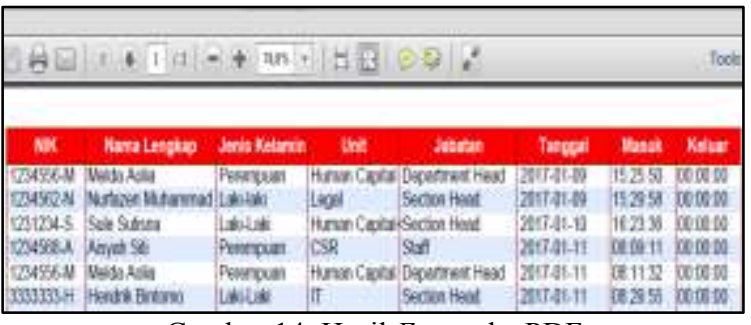

Gambar 14. Hasil Export ke PDF

\section{Form Beranda User}

Form beranda user adalah halaman utama setelah Karyawan melakukan login dan absen masuk. Form Beranda Admin dapat dilihat pada Gambar 15.

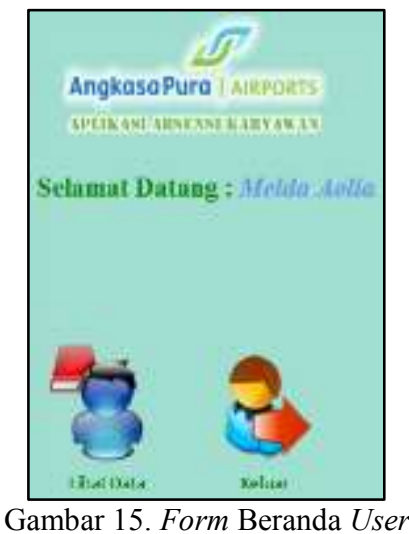

\section{Form Lihat Absen Karyawan}

Form Lihat Data Absen untuk melihat karyawan yang sudah absen dapat dilihat pada Gambar 16.

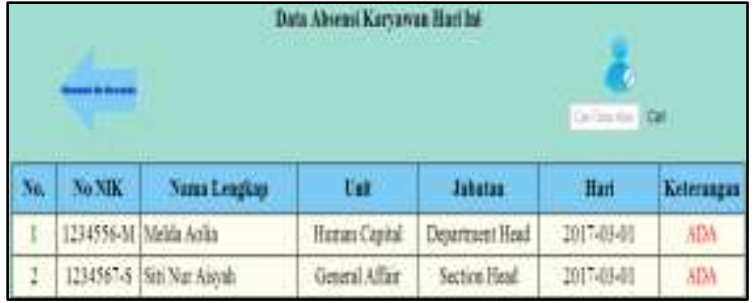

Gambar 16. Form Lihat data Absen

\section{KESIMPULAN}

Berdasarkan hasil dari pembahasan, dapat disimpulkan bahwa analisis sistem Absensi Karyawan PT. Angkasa Pura I (Persero) Banjarmasin yang menggunakan alat finger print untuk melakukan absensi. Kekurangan dari sistem yang berjalan yaitu posisi alat jauh dan untuk melakukan rekapitulasi data admin tidak dapat langsung memonitoring dari PCnya. Membangun database Aplikasi Absensi Karyawan PT. Angkasa Pura I (Persero) Banjarmasin dengan menggunakan MySQL dan merancangnya dengan ERD, PDM dan CDM. Memodelkan Aplikasi Absensi Karyawan PT. Angkasa Pura I (Persero) Banjarmasin dengan menggunakan UML. Pengkodean Aplikasi Absensi Karyawan PT. Angkasa Pura I (Persero) Banjarmasin dengan bahasa PHP dan tools XAMPP dan Notepad++, serta mengimplementasikan Aplikasi Absensi Karyawan PT. Angkasa Pura I (Persero) Banjarmasin untuk membantu karyawan melakukan absensi dari ruangan karyawan tanpa harus ke ruang lobby dan membantu admin mengolah laporan absensi karyawan, serta memberi fasilitas General Manager untuk memonitoring absensi karyawan.

\section{DAFTAR PUSTAKA}

Hendrayudi. 2009. VB 2008 untuk Berbagai Keperluan Pemograman. Jakarta: Elex Media Komputindo.

Nugroho, B. 2007. Membuat Aplikasi Database SQL Server dengan Visual Basic 6.0. Yogyakarta: Gava Media.

Shalahuddin, M. dan Rosa A. S. 2013. Rekayasa Perangkat Lunak Terstruktur dan Berorientasi Objek. Bandung : Informatika.

\section{Biodata Penulis}

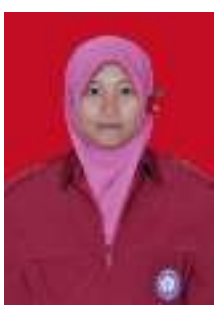

Siti Nur Aisyah, lahir di Pelaihari pada tanggal 25 Agustus. Penulis pertama menyelesaikan Sekolah Menengah Atas pada tahun 2014 dan melanjutkan pendidikan ke Politeknik Negeri Tanah Laut. Saat ini penulis pertama telah menempuh semester VI di Jurusan Teknik Informatika Politeknik Negeri Tanah Laut dan sedang menyelesaikan Tugas Akhir untuk memperoleh gelar A.Md.

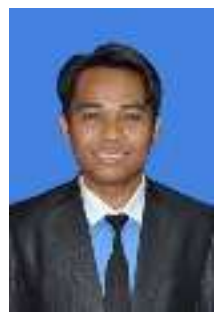

Khairul Anwar Hafizd, lahir di Gambut pada tanggal 1 Juni 1989. Penulis kedua memperoleh gelar S.Kom dalam bidang Informatika STTI pada tahun 2011, kemudian melanjutkan pendidikan Strata 2 di Jurusan Sistem Informasi Bisnis di LIKMI Bandung dan memperoleh gelar M.Kom pada tahun 
2014. Selama penulis menempuh pendidikan Strata 2 , penulis memfokuskan untuk mengkaji bidang Sistem Informasi terutama yang berhubungan dengan Sistem Informasi Bisnis. Setelah memperoleh gelar Magister, penulis bekerja menjadi Dosen di Jurusan Teknik Informatika Politeknik Negeri Tanah Laut dari tahun 2015 s/d sekarang. 